\title{
STRATEGI PENINGKATAN KUALITAS LAPORAN KEUANGAN BADAN LITBANG DAN INOVASI (KANTOR JAKARTA DAN BOGOR)
}

\author{
The Strategy for Improving the Quality of Financial Statements Research, Development and \\ Innovation Agency (Jakarta and Bogor Offices) \\ Hengki Permadi ${ }^{1}$, Hermanto Siregar ${ }^{2}$, Nirwan Ristiyanto ${ }^{2}$ \\ ${ }^{1}$ Staf pada Sekretariat Badan Litbang dan Inovasi. Email: arjoena74@gmail.com \\ ${ }^{2}$ Staff Pengajar (Dosen) pada Fakultas Ekonomi dan Manajemen, IPB. Email: \\ hermansiregar@yahoo.com,nirwanristiyanto@yahoo.com
}

\begin{abstract}
The good quality of financial statements of the government can describe the good performance of governance management. The purpose of this study was to obtain a policy strategy to improve the quality of financial reports of Research, Development and Innovation Agency (RDIA) and to determine factors that influence the quality of financial report, and in the end could be hoped to get the better opinions of BPK. This study used questionnaires that distributed to respondents from technical unit of RDIA throughout Indonesia. SWOT and QSPM analysis methods were used in this study. The results of the study with SWOT analysis produced some priority strategy in the form of Strength-Opportunities combinations (SO). To get a better strategy, QSPM analysis was used with the results that RDIA should improve human resources capacity, especially for operator staffs that appropriate with educational background and enhancement of role and responsibilities of the leaders division on the financial statements as well.
\end{abstract}

\begin{abstract}
ABSTRAK
Laporan keuangan pemerintah yang berkualitas baik dapat menggambarkan kinerja pengelolaan kepemerintahan yang baik. Tujuan penelitian ini adalah memperoleh strategi kebijakan untuk meningkatkan kualitas laporan keuangan Badan Litbang dan Inovasi dan menentukan faktor-faktor yang mempengaruhi kualitas laporan keuangan. Strategi peningkatan kualitas laporan keuangan dapat menghasilkan opini BPK RI yang lebih baik. Penelitian ini menggunakan kuesioner kepada responden dari satuan kerja lingkup Badan Litbang dan Inovasi seluruh Indonesia. Penelitian ini menggunakan metode analisis SWOT dan analisis QSPM. Hasil penelitian dengan metode SWOT menghasilkan beberapa strategi prioritas dari kombinasi Kekuatan-Peluang (SO). Untuk mendapatkan strategi yang lebih baik digunakan analisis QSPM dengan hasil strategi yang perlu dilakukan Badan Litbang dan Inovasi yaitu peningkatan sumber daya manusia terutama petugas operator sesuai kriteria dan pendidikan serta peningkatan peran dan tanggung jawab pimpinan terhadap laporan keuangan.
\end{abstract}

\section{PENDAHULUAN}

Laporan keuangan pemerintah yang berkualitas baik dapat menggambarkan kinerja pengelolaan kepemerintahan yang baik (good governance). Menurut Peraturan Pemerintah (PP) Nomor 71 Tahun 2010 bahwa laporan keuangan yang baik adalah laporan keuangan memiliki karakteristik kualitatif laporan keuangan yaitu andal, relevan, dapat dibandingkan dan dapat dipahami, sedangkan sampai saat ini masih terdapat lembaga atau kementerian laporan keuangan belum sesuai PP Nomor 71 Tahun 2010. Laporan keuangan adalah suatu alat pertanggungjawaban kinerja keuangan manajemen suatu pemerintahan kepada publik yang dipercayakan kepadanya (Prasetya 2005). Hal ini berarti laporan 
keuangan dapat dimanfaatkan oleh pengguna terutama penentu kebijakan dan pengambil keputusan yang dapat membawa kepada pengelolaan pemerintahan yang lebih baik.

Penilaian BPK terhadap laporan keuangan Kementerian Lingkungan Hidup dan Kehutanan Tahun 2015 memberikan opini Wajar Dengan Pengecualian ${ }^{1}$. Penilaian ini menurun jika dibandingkan tahuntahun sebelumnya yang mencapai opini Wajar Tanpa Pengecualian seperti terlihat pada Tabel 1 .

Tabel 1 Opini BPK RI terhadap LK Kementerian Lingkungan Hidup dan Kehutanan tahun 2011 2015

\begin{tabular}{lccccc}
\hline \multicolumn{1}{c}{ Nama Kementerian } & 2011 & 2012 & 2013 & 2014 & 2015 \\
\hline Kementerian Kehutanan & WTP-DPP & WTP-DPP & WTP & WTP & \\
$\begin{array}{l}\text { Kementerian Lingkungan } \\
\text { Hidup }\end{array}$ & WTP-DPP & WTP-DPP & WTP & WTP & \\
$\begin{array}{l}\text { Kementerian Lingkungan } \\
\text { Hidup dan Kehutanan }\end{array}$ & & & & & WDP* \\
* Kementerian setelah digabung & & & & &
\end{tabular}

Pada tahun 2015 implementasi basis akrual telah diterapkan sehingga penggunaan aplikasi keuangan sebagai bahan penyusunan laporan keuangan sudah berbasis akrual. Salah satu yang mempengaruhi penilaian adalah faktor sumber daya manusia yang kurang memahami dalam penyusunan laporan keuangan, dalam hal ini berbasis akrual.

Laporan keuangan yang baik disusun oleh tenaga atau personil yang memiliki kemampuan dan pengetahuan yang baik dalam hal akuntansi, terutama akuntansi berbasis akrual. Sesuai penelitian Wati et. al. (2014) menyatakan bahwa kompetensi sumberdaya manusia berpengaruh positif dan sigifikan terhadap kualitas laporan keuangan daerah, yang berarti semakin baik kompetensi sumber daya manusia, maka akan meningkatkan kualitas laporan keuangan daerah. Menurut Nugraheni dan Subaweh (2008) menyatakan bahwa kualitas laporan keuangan yang relevan, andal, dapat dibandingkan dan dapat dipahami, dipengaruhi dengan penerapan sistem akuntansi pemerintahan (SAP) yang baik, pengetahuan pengelola UAPPA-E1 dan ketersediaan sarana dan prasarana yang memadai.

Badan Litbang dan Inovasi merupakan salah satu entitas pemerintah yang menyusun dan membuat laporan keuangan pemerintah di bawah Kementerian Lingkungan Hidup dan Kehutanan. Hal ini sesuai dengan Undang-Undang Nomor 17 Tahun 2003 tentang Keuangan Negara, Pasal 9 menyatakan bahwa Menteri/pimpinan lembaga sebagai pengguna anggaran/pengguna barang kementerian negara/lembaga yang dipimpinnya mempunyai tugas menyusun dan menyampaikan laporan keuangan kementerian negara/lembaga yang dipimpinnya. Laporan keuangan tingkat satuan kerja disusun oleh petugas operator keuangan. Petugas operator baik keuangan dan barang lingkup Badan Litbang dan Inovasi memiliki latar belakang pendidikan yang berbeda-beda, sehingga pemahaman terhadap akuntansi pada umumnya tidak sama. Hal ini pula yang mengakibatkan laporan keuangan setiap satker berbeda-beda penyusunan dan penyajiannya dan tidak diyakini kewajarannya.

Implementasi akuntansi berbasis akrual tersebut tidak dibarengi dengan aplikasi yang terintegrasi antara aplikasi keuangan dengan aplikasi barang milik negara. Hal tersebut menyebabkan laporan

\footnotetext{
${ }^{1}$ Sumber: LHP BPK RI atas LKPP Tahun 2015, Ringkasan Eksekutif
} 
keuangan semakin kurang diyakini kewajarannya. Oleh sebab itu, perlu adanya pelatihan atau sosialisasi mengenai tatacara penyusunan laporan keuangan dengan menggunakan aplikasi. Dalam hal ini, Kementerian Keuangan melalui perwakilan di daerah hanya memberikan sosialisasi pelaporan keuangan kurang dari satu hari sehingga kendala atau permasalahan yang dihadapi oleh petugas operator di lapangan belum dapat teratasi dengan baik.

Salah satu upaya yang dapat dilakukan oleh Badan Litbang dan Inovasi dalam meningkatkan kualitas laporan keuangan dengan meningkatkan kompetensi dan pengetahuan operator keuangan dalam penyusunan laporan keuangan. Sebaliknya atasan langsung sebagai pihak yang bertanggungjawab terhadap laporan keuangan perlu diberikan pemahaman mengenai penyusunan laporan keuangan yang seusai dengan PP Nomor 71 Tahun 2010.

Mulai tahun 2015 penyusunan laporan keuangan menggunakan aplikasi keuangan yang berbasis akrual. Walau demikian, penggunaan aplikasi tersebut masih terkendala dalam penggabungan atau integrasi antar aplikasi keuangan dengan aplikasi barang milik negara. Hal ini menyebabkan operator keuangan kesulitan dalam penyusunan laporan keuangan, apalagi dengan ditambah latar belakang pendidikan operator yang bukan berasal dari sarjana ekonomi.

Permasalahan-permasalahan tersebut seharusnya dapat diatasi dengan adanya sosialisasi dan bimbingan teknis terhadap petugas operator untuk meningkatkan pengetahuan dan kompetensinya dalam penyusunan laporan keuangan. Selama ini sosialisasi dan bimbingan teknis yang diberikan kepada petugas operator jarang dilakukan, baik oleh kementerian sendiri maupun dari kementerian keuangan.

Hasil penelitian terdahulu yang dilakukan Yuliani, et al (2010), Charlina dan Husaini (2013) serta Juwita (2013) menunjukkan bahwa pemahaman akuntansi, pemanfaatan sistem akuntansi keuangan dan implementasi standar akuntansi pemerintahan berpengaruh positif terhadap kualitas laporan keuangan.

Berdasarkan permasalahan di atas maka kajian ini dilakukan untuk:

1. Menganalisis kompetensi dan kemampuan (pengetahuan) operator keuangan dan kebijakan atasan langsung berpengaruh terhadap kualitas laporan keuangan.

2. Menganalisis aplikasi Sistem Akuntansi Instansi dan Implementasi Akuntansi Berbasis Akrual berpengaruh pada kualitas laporan keuangan.

3. Menganalisis kaitan antara bimbingan teknis dan sosialisasi operator keuangan dengan kualitas laporan keuangan

4. Strategi yang dapat dilakukan untuk meningkatkan kualitas laporan keuangan Badan Litbang dan Inovasi.

\section{TINJAUAN PUSTAKA}

\section{Strategi}

Strategi menurut Solihin (2012) didefinisikan sebagai berbagai cara untuk mencapai tujuan (ways to achieve ends). Menurut Alfred Chandler dalam Solihin (2012) strategi adalah the determination of longterm goals of an enterprise and the adoption of courses of action and the allocation of resources 
necessary for carrying out these goals atau suatu penentuan sasaran dan tujuan dasar jangka panjang dari suatu organisasi (perusahaan) serta pengadopsian seperangkat tindakan serta alokasi sumbersumber yang perlu untuk mencapai sasaran-sasaran tersebut. Umumnya strategi akan berubah sewaktuwaktu sesuai kebutuhan dan berdasarkan sudut pandang perencanaannya. Hal ini sesuai dengan pendapat Hamel dan Prahalad dalam Rangkuti (2015) menyatakan bahwa strategi merupakan tindakan yang bersifat incremental (senantiasa meningkat) dan terus-menerus dan dilakukan berdasarkan sudut pandang tentang apa yang diharapkan oleh para pelanggan di masa depan. Dengan demikian, perencanaan strategi hampir selalu dimulai dari "apa yang dapat terjadi", bukan dimulai dari "apa yang terjadi”.

\section{Laporan Keuangan}

Laporan keuangan (financial statements) adalah dokumen perusahaan yang melaporkan sebuah perusahaan dalam istilah moneter yang menyediakan informasi untuk membantu seseorang membuat keputusan bisnis berdasarkan informasi tersebut (Horngren dan Harrison 1996). Dalam mempertanggungjawabkan dan akuntabilitas, pemerintah selaku penyelenggara negara wajib menyampaikan laporan pertanggungjawaban keuangan. Laporan pertanggungjawaban tersebut harus memenuhi prinsip-prinsip tepat waktu dan disusun dengan mengikuti Standar Akuntansi Pemerintah yang telah diterima umum. Laporan keuangan adalah bentuk pertanggungjawaban pemerintah atas pelaksanaan APBN berupa laporan realisasi anggaran, neraca, laporan arus kas, laporan operasional, laporan perubahan ekuitas, laporan perubahan saldo anggaran lebih, dan catatan atas laporan keuangan (Pasal 1, PP Nomor 71 Tahun 2010).

\section{Unsur-unsur Laporan Keuangan}

Unsur-unsur Laporan Keuangan Pemerintah sesuai PP Nomor 71 Tahun 2010 berbasis akrual terdiri dari: 1) Laporan Realisasi Anggaran, 2) Laporan Perubahan Saldo Anggaran Lebih, 3) Neraca, 4) Laporan Operasional, 5) Laporan Perubahan Ekuitas, 6) Laporan Arus Kas dan 7) Catatan atas Laporan Keuangan. Unsur-unsur Laporan Keuangan tersebut merupakan unsur-unsur yang harus dipenuhi oleh Kementerian/Lembaga yang mengelola keuangan secara penuh, seperti Kementerian Keuangan. Sedangkan Kementerian Lingkungan Hidup dan Kehutanan dalam penyusunan laporan keuangan, unsur-unsur laporan keuangan yang harus dipenuhi adalah 1) Laporan Realisasi Anggaran, 2) Neraca, 3) Laporan Operasional, 4) Laporan Perubahan Ekuitas, dan 5) Catatan atas Laporan Keuangan.

Basis akuntansi yang digunakan saat ini adalah basis akrual. Basis akrual menurut Statements of Standard Accounting Practice 2 (SSAP 2) dalam Bastian (2010) adalah penerimaan dan biaya bertambah (diakui karena diperoleh atau dimasukkan bukan sebagai uang yang diterima atau dibayarkan) dalam jumlah yang sesuai satu sama lain, dapat dipertahankan atau dianggap benar, dan berkaitan dengan rekening laba dan rugi selama periode bersangkutan. Selanjutnya menurut Horngren 
dan Harrison (1996) akuntansi akrual (accrual accounting) mencatat dampak dari setiap transaksi pada saat terjadinya.

\section{Sistem Akuntansi Instansi}

Program Sistem Akuntansi Instansi menurut Perdanawati (2014) adalah proses pendesentralisasian atas sistem akuntansi pemerintahan yang dilaksanakan oleh pemerintah pusat kepada unit-unit instansi terkait dengan penggunaan anggaran negara dalam setiap pelaksanaan kegiatan pemerintahan yang dilakukan dengan prosedur manual dan sistem komputerisasi dalam proses pencatatan dan pelaporan keuangan setiap instansi pemerintah yang harus dipertanggungjawabkan oleh kepala kantor suatu instansi sebagai kuasa pengguna anggaran yang memiliki peran sebagai pengkoordinir dari pelaksanaan program sistem akuntansi yang dikelolanya.

\section{Sumber Daya Manusia}

Manajemen sumber daya manusia (human resources management) adalah proses untuk memperoleh, melatih, menilai dan mengompensasi karyawan dan untuk mengurus relasi tenaga kerja, kesehatan dan keselamatan serta hal-hal yang berhubungan dengan keadilan (Dessler 2015). Pengelolaan sumber daya manusia tersebut, meliputi analisis pekerjaan, kebutuhan tenaga kerja, orientasi dan melatih karyawan, penilaian kinerja, membangun komitmen karyawan dan komunikasi antara karyawan dan manajemen (Dessler 2015).

Menurut Charlina, et al. (2013) bahwa pengalaman kerja berpengaruh positif dan signifikan terhadap kualitas laporan keuangan. Hal ini menunjukkan bahwa semakin tinggi tingkat pengalaman kerja yang dimiliki pegawai maka semakin tinggi pula tingkat kualitas laporan keuangan pada suatu organisasi. Pada penelitian Handayani (2012) salah satu faktor yang mempengaruhi kualitas laporan keuangan pemerintah daerah adalah keterbatasan sumberdaya manusia yang menguasai bidang akuntansi di daerah. Sebagian besar satuan kerja perangkat daerah (SKPD) tidak memahami akuntansi disebabkan latar belakang pendidikan dan kompetensi serta pengalaman dalam pengelolaan keuangan berbasis akrual.

\section{Sistem Pengendalian Intern Pemerintah}

Sistem pengendalian intern adalah proses yang integral pada tindakan dan kegiatan yang dilakukan secara terus menerus oleh pimpinan dan seluruh pegawai untuk memberikan keyakinan memadai atas tercapainya tujuan organisasi melalui kegiatan yang efektif dan efisien, keandalan pelaporan keuangan, pengamanan aset negara dan ketaatan terhadap peraturan perundang-undangan (UU Nomor 60 Tahun 2008 Pasal 1). Sistem Pengendalian Intern Pemerintah adalah Sistem Pengendalian Intern yang diselenggarakan secara menyeluruh di lingkungan pemerintah pusat dan pemerintah daerah.

Hasil penelitian yang dilakukan oleh Nofianti dan Suseno (2014) menerangkan bahwa kompetensi aparat pemerintah daerah dan profesionalisme aparat pengendalian intern mempengaruhi 
pelaksanaan tata pemerintahan yang baik (GGG). Selain itu, kompetensi dan profesionalisme tersebut dipengaruhi juga oleh akuntabilitas kinerja.

\section{Kualitas Laporan Keuangan}

Karakteristik laporan keuangan yang berkualitas menurut PP Nomor 71 Tahun 2010 adalah laporan yang memenuhi kualitas yang dikehendaki yaitu relevan, andal, dapat dibandingkan dan dapat dipahami. Penelitian yang dilakukan Juwita (2013) bahwa pelaksanaan standar akuntansi pemerintahan berpengaruh siginifikan terhadap kualitas laporan keuangan. Selanjutnya implementasi sistem informasi akuntansi pemerintahan berpengaruh sangat signifikan terhadap kualitas laporan keuangan dengan ditandai pengolahan data menggunakan software yang baik menghasilkan laporan keuangan yang baik. Pengolahan data yang baik menjadikan informasi keuangan terdokumentasi dengan baik dan lengkap sehingga laporan keuangan dapat dimanfaatkan dengan baik oleh pengambil keputusan.

Laporan keuangan terutama digunakan untuk membandingkan realisasi pendapatan, belanja, transfer, dan pembiayaan dengan anggaran yang telah ditetapkan, menilai kondisi keuangan, mengevaluasi efektivitas dan efesiensi suatu entitas pelaporan, dan membantu menentukan ketaatannya terhadap peratuan perundang-undangan.

\section{METODE PENELITIAN}

Metode pengumpulan data dalam penelitian ini dengan melakukan penelitian survei dengan pengumpulan data primer dengan menggunakan kuesioner kepada responden yang telah ditentukan. Kuesioner penelitian digabungkan dengan wawancara. Data sekunder berupa observasi langsung terhadap dokumen sumber dan studi pustaka.

Populasi responden adalah satuan kerja lingkup Badan Litbang dan Inovasi di seluruh Indonesia. Populasi responden terdiri atas responden penelitian dengan metode analisis SWOT (SWOT analysis) dan responden penelitian dengan metode analisis QSPM (QSPM analysis). Responden penelitian untuk analisis SWOT terdiri atas operator SAIBA, operator SIMAK BMN, operator aplikasi persediaan dan kepala sub bagian tata usaha. Responden penelitian untuk analisis QSPM adalah Sekretaris Badan Litbang dan Inovasi sebagai pengambil keputusan dan pemangku kebijakan untuk penetapan strategi. 
Tabel 1 Populasi dan sampel

\begin{tabular}{|c|c|c|c|}
\hline No. & $\begin{array}{r}\text { Uraian } \\
\end{array}$ & Jumlah & Keterangan \\
\hline 1 & Sekretaris Badan & 1 orang & Analisis QSPM \\
\hline 2 & Kepala Bagian Keuangan dan Umum & 1 orang & Analisis SWOT \\
\hline 3 & $\begin{array}{l}\text { Kepala Bagian Akuntansi dan Pelaporan, } \\
\text { Biro Keuangan }\end{array}$ & 1 orang & Analisis SWOT \\
\hline 4 & Kepala Bagian Tata Usaha & 6 orang & Analisis SWOT \\
\hline 5 & $\begin{array}{l}\text { Kepala Sub Bagian Administrasi } \\
\text { Keuangan }\end{array}$ & 1 orang & Analisis SWOT \\
\hline 6 & Kepala Sub Bagian Perlengkapan & 1 orang & Analisis SWOT \\
\hline 7 & $\begin{array}{l}\text { Kepala Sub Bagian Keuangan dan } \\
\text { Perlengkapan }\end{array}$ & 4 orang & Analisis SWOT \\
\hline 8 & Kepala Sub Bagian TU & 15 orang & Analisis SWOT \\
\hline 9 & Operator Aplikasi & 60 orang & Analisis SWOT \\
\hline
\end{tabular}

Tahap awal melakukan analisis adalah mengindentifikasi terhadap faktor-faktor internal dan eksternal (IFAS dan EFAS) yang ada pada Badan Litbang dan Inovasi yang dianggap berpengaruh positif maupun negatif terhadap peningkatan kualitas laporan keuangan. Pengindetfikasian faktor-faktor internal dan eksternal berdasarkan hal-hal yang mendasar yang terjadi pada satuan kerja Badan Litbang dan Inovasi pada umumnya.

Penilaian dari responden terhadap faktor-faktor tersebut yang telah dirumuskan tersebut terdiri atas 1) penilaian terhadap prestasi faktor dengan skala 1 sampai dengan 9, dengan kriteria: skala 1 berarti amat sangat buruk; skala 2 berarti sangat buruk; skala 3 berarti buruk; skala 4 berarti sedikit buruk; skala 5 berarti sedang/netral; skala 6 berarti sedikit baik; skala 7 berarti baik; skala 8 berarti sangat baik; skala 9 berarti amat sangat baik. 2) penilaian tingkat kepentingan terhadap penanganan faktor-faktor dengan menentukan skala a sampai dengan d dengan kriteria: skala a berarti sangat penting untuk dilakukan penanganan; skala $\mathrm{b}$ berarti penting untuk dilakukan penanganan; skala $\mathrm{c}$ berarti kurang penting untuk dilakukan penanganan; dan skala d berarti tidak penting untuk dilakukan penanganan. Penilaian terhadap faktor-faktor internal dan eksternal dengan menentukan nilai rata-rata, kemudian nilai rata-rata tersebut diidentifikasi unsur-unsur yang diklasifikasikan sebagai kekuatan (strength), kelemahan (weakness), kesempatan dan peluang (opportunity) dan ancaman (threat) yang dimiliki oleh Badan Litbang dan Inovasi dalam peningkatan kualitas laporan keuangan.

\section{Perumusan Strategi dalam Analisa SWOT}

Langkah selanjutnya adalah menggunakan metode analisis SWOT. Analisis SWOT (Strenghts, Weaknesses, Opportunities dan Threats) untuk merumuskan strategi dengan menggunakan matriks analisis SWOT. Perumusan strategi dilakukan dengan pembobotan terhadap faktor-faktor internal dan eksternal dalam elemen-elemen SWOT, dengan langkah-langkah berikut:

1. Setiap nilai rata-rata horizontal dikurangi nilai 5 (lima) sebagai nilai dari persepsi/pendapat responden yang lebih adil atas pembagian faktor internal menjadi strength dan weakness, dan faktor eksternal menjadi opportunity dan threat. Nilai 5 (lima) diambil sebagai patokan (benchmark) yang 
berkorelasi netral terhadap sasaran. Nilai yang dihasilkan kemudian disebut sebagai penyesuaian nilai rata-rata;

2. Nilai penyesuaian bersifat nilai mutlak;

3. Penentuan bobot dari masing-masing elemen SWOT untuk setiap faktornya dengan mengambil bobot masing-masing faktor $=100 \%$. Bobot total dari setiap elemen SWOT menggambarkan total nilai penyesuaian rata-rata terhadap nilai total faktornya masing-masing;

4. Pembobotan yang dipakai sebagai bahan penilaian prioritas adalah bobot tertimbang yang diperoleh dari perkalian antara bobot $\mathrm{x}$ rating. Rating diperoleh dari nilai urgensi penanganan/skala prioritas kepentingan, sesuai dengan urutan level: huruf $a=4 ; b=3 ; c=2 ; d=1$.

Hasil penilaian dilakukan kombinasi interaksi antara faktor internal dengan faktor eksternal sehongga didapatkan strategi kombinasi dari matriks SWOT tersebut. Kombinasi interaksi antara faktor internal dan eksternal diilustrasikan dalam Tabel 2.

Tabel 2 Matriks SWOT

\begin{tabular}{|c|c|c|}
\hline $\begin{array}{l}\text { Faktor } \\
\text { Eksternal }\end{array}$ & $\begin{array}{l}\text { Kekuatan (Strenght) } \\
\text { Daftar Kekuatan }\end{array}$ & $\begin{array}{l}\text { Kelemahan (Weakness) } \\
\text { Daftar Kelemahan }\end{array}$ \\
\hline $\begin{array}{l}\text { Peluang } \\
\text { (Opportunity) } \\
\text { Daftar Peluang }\end{array}$ & $\begin{array}{l}\text { Strategi SO } \\
\text { - } \quad \text { Strategi yang } \\
\text { memaksimalkan } \\
\text { kekuatan untuk } \\
\text { memanfaatkan peluang } \\
\quad \text { yang ada } \\
\text { - } \quad \text { Strategi agresif } \\
\text { - } \quad \text { Keunggulan komparatif }\end{array}$ & $\begin{array}{l}\text { Strategi WO } \\
\text { - } \quad \text { Strategi yang } \\
\text { meminimalkan } \\
\text { kelemahan untuk } \\
\text { memanfaatkan peluang } \\
\text { - } \quad \text { Strategi orientasi putar } \\
\text { balik } \\
\text { - } \quad \text { Investasi/Divestasi } \\
\end{array}$ \\
\hline $\begin{array}{l}\text { Ancaman (Threat) } \\
\text { Daftar Ancaman }\end{array}$ & $\begin{array}{ll}\text { Strategi ST } \\
\text { - } & \text { Strategi yang } \\
\text { memaksimalkan } \\
\text { kekuatan untuk } \\
\text { mengatasi ancaman } \\
\text { - } \quad \text { Strategi diversifikasi } \\
\text { - } & \text { Mobilisasi }\end{array}$ & $\begin{array}{l}\text { Strategi WT } \\
\text { - } \quad \text { Strategi yang } \\
\text { meminimalkan } \\
\text { kelemahan untuk } \\
\text { mengatasi ancaman } \\
\text { - } \quad \text { Strategi defensif } \\
\text { - } \quad \text { Kontrol kerusakan/ } \\
\text { strategi riskan } \\
\end{array}$ \\
\hline
\end{tabular}

Sumber: Fred R. David (2004)

\section{Metode Perumusan Strategi melalui QSPM}

Metode penelitian selanjutnya adalah metode Matriks Perencanaan Strategik Kuantitatif atau Quantitative Strategic Planning Matrix (QSPM). Menurut David dan David (2015) menerangkan bahwa QSPM adalah alat yang memungkinkan penyusun strategi untuk mengevaluasi alternatif strategi secara objektif, berdasarkan faktor keberhasilan kunci internal dan eksternal yang telah diidentifikasi sebelumnya. Seperti alat analisis perumusan-strategi lainnya, QSPM membutuhkan penilaian intuitif yang baik.

Penentuan kerangka perumusan strategi yang komprehensif, QSPM menggunakan input dari analisis faktor internal dan faktor eksternal (tahap 1), dan hasil pencocokan dari analisisi untuk 
menentukan seraca objektif di antara alternatif-alternatif strategi melalui Matriks SWOT (tahap 2) dan memberikan informasi yang dibutuhkan untuk membuat QSPM (tahap 3).

Strategi-strategi tersebut merupakan hasil pengolahan data kuesioner yang telah ditentukan faktor internal dan eksternal melalui matriks SWOT. Strategi tersebut merupakan penjabaran dari tujuan penelitian ini.

Tabel 3 Matriks perencanaan strategik kuantitatif (QSPM)

\begin{tabular}{lllll} 
& & \multicolumn{3}{c}{ Alternatif-alternatif Strategi } \\
\hline \multicolumn{1}{c}{ Faktor Kunci } & Bobot & Strategi 1 & Strategi 2 & Strategi 3 \\
\hline Faktor Eksternal & & & & \\
$-\quad$ Peluang & & & \\
- & Ancaman & & \\
\hline Faktor Internal & & & \\
$-\quad$ Kekuatan & & \\
- Kelemahan & & & \\
\hline
\end{tabular}

Sumber: Strategic Management, David and David, 2015

\section{GAMBARAN UMUM}

Instansi Badan Litbang dan Inovasi telah berdiri sejak tahun 1913 dengan nama Proefstation Voor Het Boswezen (Stasiun Penelitian Untuk Kehutanan) yang bernaung di bawah Dients Van Het Boswezen (Jawatan Kehutanan) sesuai dengan Keputusan Pemerintah Nomor 58 Tahun 1913. Pada tahun 1927 nama stasiun tersebut diubah menjadi Bosbouwproefstation (Balai Penjelidikan Kehutanan, disingkat BPK).

Kemudian tahun 1983 dengan dibentuknya Departemen Kehutanan sesuai Surat Keputusan Presiden RI, Nomor 4/M/tahun 1983 tentang Kabinet Pembangunan IV, menjadi Badan Litbang Kehutanan hingga tahun 2015. Perubahan yang terjadi sesuai dengan dibentuknya Kabinet Kerja yang dibentuk pada tanggal 26 Oktober 2014 menjadikan Kementerian Kehutanan bergabung dengan Kementerian Negara Lingkungan Hidup sehingga menjadi Kementerian Lingkungan Hidup dan Kehutanan. Seiring perubahan organisasi, maka instansi Badan Litbang Kehutanan berubah menjadi Badan Litbang dan Inovasi. Berdasarkan kedua peraturan tersebut, Badan Litbang dan Inovasi adalah pelaksana program penelitian, pengembangan dan inovasi di bidang lingkungan hidup dan kehutanan yang bertanggung jawab kepada Menteri Lingkungan Hidup dan Kehutanan.

Badan Litbang dan Inovasi terdiri dari 5 satuan kerja pusat dan 15 satuan kerja di daerah. Satuan kerja pusat terdiri dari: 1) Sekreariat Badan Litbang dan Inovasi 2) Pusat Litbang Hutan, 3) Pusat Litbang Hasil Hutan, 4) Pusat Litbang Kualitas dan Laboratorium Lingkungan, dan 5) Pusat Litbang Sosial, Ekonomi, Kebijakan dan Perubahan Iklim. Satuan kerja di daerah terdiri dari: 1) Balai Besar Penelitian Bioteknologi dan Pemuliaan Tanaman Hutan (BBPBPTH) Yogyakarta, 2) Balai Besar Penelitian Dipterokarpa (BBPD) Samarinda, 3) Balai Penelitian Teknologi Agroforestry (BPTA) Ciamis, 4) Balai Penelitian Teknologi Perbenihan Tanaman Hutan (BPTPTH) Bogor, 5) Balai Penelitian 
Teknologi Hasil Hutan Bukan Kayu (BPTHHBK) Mataram NTB, 6) Balai Penelitian Teknologi Kehutanan Pengelolaan DAS (BPTKPDAS) Solo, 7) Balai Penelitian Teknologi Konservasi Sumberdaya Alam (BPTKSDA) Samboja Kaltim, 8) Balai Penelitian Teknologi Serat Tanaman Hutan (BPTSTH) Kuok Riau, 9) Balai Penelitian Kehutanan Manokwari Papua, 10) Balai Penelitian Kehutanan Banjarbaru, 11) Balai Penelitian Kehutanan Palembang, 12) Balai Penelitian Kehutanan Makassar, 13) Balai Penelitian Kehutanan Kupang, 14) Balai Penelitian Kehutanan Manado, dan 15) Balai Penelitian Kehutanan Aek Nauli.

Sampai dengan tahun 2015, Badan Litbang dan Inovasi didukung oleh sumber daya manusia yang terdiri dari Pegawai Negeri Sipil sebanyak 1709 orang dan tenaga kontrak sebanyak 302 orang.

\section{HASIL DAN PEMBAHASAN}

\section{Hasil dan Pembahasan}

Hasil pengukuran kuesioner terhadap responden diketahui bahwa jumlah sampel responden yang diambil sebanyak 68 orang difokuskan kepada petugas operator SAIBA, SIMAK dan persediaan sebanyak 60 orang dan sisanya adalah kepala sub bagian tata usaha atau pejabat struktural eselon IV dari 20 satuan kerja lingkup Badan Litbang dan Inovasi. Pemilihan responden tersebut didasarkan atas tingkat kepentingan petugas operator dan pejabat eselon IV yang menangani langsung penyusunan laporan keuangan sesuai bahan laporan melalui aplikasi keuangan dan barang milik negara.

Hasil pengukuran kusioner dari responden dapat dilihat bahwa usia petugas operator sangat beragam. Berdasarkan data kuesioner, usia petugas operator lingkup Badan Litbang dan Inovasi mayoritas antara 27 - 36 tahun sebanyak 40\%. Hal ini dapat dikatakan bahwa regenerasi untuk petugas operator sudah lebih baik. Latar belakang pendidikan petugas operator lingkup Badan Litbang dan Inovasi saat ini sangat beragam. Latar pendidikan S1 mendominasi dengan jumlah sebanyak 39\% dari sampel atau berjumlah 26 orang dan hanya 8 orang yang berlatar belakang pendidikan S1 Akuntansi. Selama ini petugas operator hanya mendapatkan pembekalan sosialisasi dari KPPN setempat, dan dilaksanakan jika ada aplikasi terbaru atau penggunaan aplikasi keuangan yang mendukung pelaporan keuangan. Petugas operator kurang dibekali mengenai materi penjurnalan untuk memudahkan dalam penyusunan laporan keuangan.

\section{Perumusan Strategi melalui Analisis SWOT}

Dalam penelitian ini, dilakukan analisis SWOT (Strenght, Weakness, Opportunity and Threat) terhadap kuesioner yang telah dibagikan kepada responden yang telah ditentukan. Analisis tersebut dilakukan untuk melihat dan meneliti faktor-faktor apa saja yang mempengaruhi dalam penentuan kebijakan strategis yang akan diambil oleh pengambil keputusan terutama pimpinan instansi.

Tahap awal melakukan analisis SWOT adalah mengindentifikasi terhadap faktor-faktor internal dan eksternal yang ada pada Badan Litbang dan Inovasi yang dianggap berpengaruh positif maupun negatif terhadap peningkatan kualitas laporan keuangan. Analisa SWOT adalah identifikasi berbagai faktor secara sistematis untuk merumuskan strategi perusahaan. Analisis ini didasarkan pada logika yang 
dapat memaksimalkan kekuatan (Strength) dan peluang (Opportunity), namun secara bersamaan dapat meminimalkan kelemahan (Weakness) dan ancaman (Threats). Proses pengambilan keputusan strategis selalu berkaitan dengan pengembangan misi, tujuan, strategi dan kebijakan perusahaan (Rangkuti 2015). Selanjutnya ditentukan faktor-faktor internal dan eksternal dengan pembobotan IFAS dan EFAS untuk menentukan kekuatan (Strength) dan peluang (Opportunity), serta kelemahan (Weakness) dan ancaman (Threats). Tabel 4 memperlihatkan penilaian pembobotan faktor internal (IFAS) dan Tabel 5 memperlihatkan penilaian pembobotan faktor eksternal (EFAS). 
Tabel 4 Penilaian pembobotan faktor internal (IFAS)

\begin{tabular}{|c|c|c|c|c|c|c|}
\hline $\begin{array}{l}\text { Faktor } \\
\text { Internal }\end{array}$ & $\begin{array}{l}\text { Faktor } \\
\text { No. }\end{array}$ & Rata-rata & $\begin{array}{c}\text { Penyesuaian } \\
\text { Nilai Rata-rata }\end{array}$ & $\begin{array}{l}\text { Bobot (\%) } \\
(\mathrm{B} / \mathrm{Xsi}) * \mathrm{BS}\end{array}$ & $\begin{array}{l}\text { Urgensi } \\
\text { (rating) }\end{array}$ & $\begin{array}{c}\text { Bobot } \mathrm{x} \\
\text { Rating }\end{array}$ \\
\hline \multirow{8}{*}{$\begin{array}{l}\text { Kekuatan } \\
\text { (Strength) }\end{array}$} & 7 & 7.76 & 2.76 & 10.62 & 3.41 & 0.36 \\
\hline & 8 & 7.41 & 2.41 & 9.26 & 3.26 & 0.30 \\
\hline & 9 & 7.35 & 2.35 & 9.03 & 3.38 & 0.31 \\
\hline & 10 & 7.59 & 2.59 & 9.94 & 3.41 & 0.34 \\
\hline & 11 & 7.38 & 2.38 & 9.15 & 3.38 & 0.31 \\
\hline & 12 & 7.53 & 2.53 & 9.71 & 3.40 & 0.33 \\
\hline & & Total S (Xsi) & 15.03 & & & 1.95 \\
\hline & & Rata-rata & $\begin{array}{c}\text { Penyesuaian } \\
\text { Nilai Rata-rata }\end{array}$ & $\begin{array}{c}\text { Bobot (\%) } \\
(\mathrm{B} / \mathrm{Xwi})^{*} \mathrm{~B} \\
\text { W }\end{array}$ & $\begin{array}{l}\text { Urgensi } \\
\text { (rating) }\end{array}$ & $\begin{array}{c}\text { Bobot } x \\
\text { Rating }\end{array}$ \\
\hline \multirow{10}{*}{$\begin{array}{l}\text { Kelemahan } \\
\text { (Weakness) }\end{array}$} & 1 & 6.66 & 1.66 & 6.38 & 3.46 & 0.22 \\
\hline & 2 & 6.79 & 1.79 & 6.89 & 3.51 & 0.24 \\
\hline & 3 & 6.69 & 1.69 & 6.49 & 3.46 & 0.22 \\
\hline & 4 & 6.82 & 1.82 & 7.00 & 3.21 & 0.22 \\
\hline & 5 & 6.97 & 1.97 & 7.57 & 3.44 & 0.26 \\
\hline & 6 & 7.07 & 2.07 & 7.96 & 3.43 & 0.27 \\
\hline & & Total W (Xwi) & 11.01 & & & 1.44 \\
\hline & & $\mathrm{Xi}=(\mathrm{Xsi}+\mathrm{Xwi})$ & 26.04 & & & 3.39 \\
\hline & & $\mathrm{Bs}=(\mathrm{Xsi} / \mathrm{Xi})^{*} 100 \%$ & \multicolumn{4}{|c|}{57.71} \\
\hline & & $\mathrm{Bw}=(\mathrm{Xw} / \mathrm{Xi}) * 100 \%$ & \multicolumn{4}{|c|}{42.29} \\
\hline
\end{tabular}

Sumber: Data diolah (2016)

Tabel 5 Penilaian pembobotan faktor eksternal (EFAS)

\begin{tabular}{|c|c|c|c|c|c|c|}
\hline Faktor Eksternal & $\begin{array}{l}\text { Faktor } \\
\text { No. }\end{array}$ & Rata-rata & $\begin{array}{c}\text { Penyesuaian } \\
\text { Nilai Rata-rata }\end{array}$ & $\begin{array}{c}\text { Bobot (\%) } \\
\text { (B/Xoi)*B } \\
\text { O }\end{array}$ & $\begin{array}{l}\text { Urgensi } \\
\text { (rating) }\end{array}$ & $\begin{array}{c}\text { Bobot } x \\
\text { Rating }\end{array}$ \\
\hline \multirow{7}{*}{$\begin{array}{c}\text { Peluang } \\
\text { (Opportunity) }\end{array}$} & 8 & 7.24 & 2.24 & 9.87 & 3.38 & 0.33 \\
\hline & 9 & 7.53 & 2.53 & 11.17 & 3.37 & 0.38 \\
\hline & 10 & 7.60 & 2.60 & 11.49 & 3.29 & 0.38 \\
\hline & 11 & 7.60 & 2.60 & 11.49 & 3.37 & 0.39 \\
\hline & 12 & 7.19 & 2.19 & 9.68 & 3.35 & 0.32 \\
\hline & & Total O (XOi) & 12.16 & & & 1.80 \\
\hline & & Rata-rata & $\begin{array}{c}\text { Penyesuaian } \\
\text { Nilai Rata-rata }\end{array}$ & $\begin{array}{l}\text { Bobot (\%) } \\
(\mathrm{B} / \mathrm{Xti}) * \mathrm{BT}\end{array}$ & $\begin{array}{l}\text { Urgensi } \\
\text { (rating) }\end{array}$ & $\begin{array}{c}\text { Bobot } \mathrm{x} \\
\text { Rating }\end{array}$ \\
\hline \multirow{11}{*}{$\begin{array}{l}\text { Ancaman } \\
\text { (Threat) }\end{array}$} & 1 & 6.75 & 1.75 & 7.73 & 3.49 & 0.27 \\
\hline & 2 & 6.59 & 1.59 & 7.01 & 3.43 & 0.24 \\
\hline & 3 & 6.81 & 1.81 & 7.99 & 3.38 & 0.27 \\
\hline & 4 & 6.81 & 1.81 & 7.99 & 3.28 & 0.26 \\
\hline & 5 & 6.68 & 1.68 & 7.40 & 3.26 & 0.24 \\
\hline & 6 & 6.85 & 1.85 & 8.18 & 3.25 & 0.27 \\
\hline & 7 & 6.59 & 1.59 & 7.01 & 3.35 & 0.24 \\
\hline & & Total T (XTi) & 10.49 & & & $\mathbf{1 . 5 5}$ \\
\hline & & $\mathrm{Xi}=(\mathrm{XOi}+\mathrm{XTi})$ & 22.65 & & & 3.35 \\
\hline & & $\mathrm{BO}=(\mathrm{XOi} / \mathrm{Xi}) * 100 \%$ & \multicolumn{4}{|c|}{53.70} \\
\hline & & $\mathrm{BT}=(\mathrm{XTi} / \mathrm{Xi}) * 100 \%$ & \multicolumn{4}{|c|}{46.30} \\
\hline
\end{tabular}

Sumber: Data diolah (2016)

Selanjutnya dari analisis penilaian faktor-faktor internal dan eksteral, maka dibuatkan hasil matriks interaksi kombinasi faktor internal dan eksternal yang tersaji pada Tabel 6. 
Tabel 6 Matriks interaksi kombinasi faktor internal - eksternal (SWOT)

\begin{tabular}{|l|lc|c|}
\hline $\begin{array}{r}\text { Faktor } \\
\text { Internal } \\
\text { Faktor }\end{array}$ & Kekuatan (Strenght) & $\begin{array}{l}\text { Kelemahan } \\
\text { (Weakness) }\end{array}$ \\
\hline $\begin{array}{c}\text { Peluang (Opportunity) } \\
\text { Bobot: } 1.80\end{array}$ & Strategi SO & Bobot: 1.95 & Bobot: 1.44 \\
\hline $\begin{array}{c}\text { Ancaman (Threat) } \\
\text { Bobot: } 1.55\end{array}$ & Strategi ST & Bobot: 3.75 & $\begin{array}{c}\text { Strategi WO } \\
\text { Bobot: } 3.24\end{array}$ \\
\hline
\end{tabular}

Sumber: Data diolah (2016)

Berdasarkan hasil interaksi kombinasi antara strategi internal dan eksternal tersebut didapatkan tingkatan prioritas strategi peningkatan kualitas laporan keuangan pada Tabel 7.

Tabel $7 \quad$ Prioritas strategi

\begin{tabular}{clc}
\hline Prioritas & \multicolumn{1}{c}{ Strategi } & Bobot Nilai \\
\hline I & Kekuatan (Strength) - Peluang (Opportunity) & 3.75 \\
II & Kekuatan (Strength) - Ancaman (Threat) & 3.50 \\
III & Kelemahan (Weakness) - Peluang (Opportunity) & 3.24 \\
IV & Kelemahan (Weakness) - Ancaman (Threat) & 2.99
\end{tabular}

Sumber: Data diolah (2016)

Perumusan strategi yang dihasilkan dari kombinasi antara faktor internal dan eksternal menghasilkan strategi prioritas Kekuatan (Strength) - Peluang (Opportunity) yang terlihat dalam Tabel 8.

Tabel 8 Strategi prioritas kekuatan (Strength) - peluang (Opportunity)

\begin{tabular}{|c|c|}
\hline Kekuatan (Strength) & Peluang (Opportunity) \\
\hline $\begin{array}{l}\text { 1. } \begin{array}{l}\text { Kerjasama dan rekonsiliasi internal antara } \\
\text { operator SAIBA, SIMAK BMN dan }\end{array} \\
\text { Aplikasi Persediaan dalam penyusunan } \\
\text { laporan keuangan } \\
\text { 2. Kemudahan dalam memperoleh data-data } \\
\text { bahan penyusunan laporan keuangan } \\
\text { (data perencanaan, keuangan dan BMN) } \\
\text { 3. Tata waktu pelaporan yang sesuai dengan } \\
\text { aturan yang berlaku } \\
\text { 4. Penyusunan laporan keuangan sesuai } \\
\text { dengan Peraturan Pemerintah Nomor } 71 \\
\text { Tahun 2010 tentang SAP } \\
\text { 5. Komitmen dan partisipasi penyusun } \\
\text { laporan keuangan pada satuan kerja } \\
\text { 6. Kinerja pegawai dalam menyusun laporan } \\
\text { keuangan }\end{array}$ & $\begin{array}{l}\text { 1. Koordinasi antara Biro Keuangan dan } \\
\text { satuan kerja dalam penyusunan laporan } \\
\text { keuangan }\end{array}$ \\
\hline \multicolumn{2}{|c|}{ Strategi Kekuatan (Strength) - Peluang (Opportunity) } \\
\hline $\begin{array}{l}\text { 1. Peningkatan koordinasi dan kerjasama berb } \\
\text { perlengkapan serta pihak internal dan ekste } \\
\text { 1. Peningkatan komitmen dan partisipasi petu } \\
\text { dengan PP Nomor } 71 \text { Tahun 2010. (S5, O2 }\end{array}$ & $\begin{array}{l}\text { gai pihak baik keuangan maupun } \\
\text { nal instansi. ( } 11, \mathrm{O} 1, \mathrm{~S} 2, \mathrm{O} 2) \\
\text { as dalam penyusunan laporan keuangan sesuai } \\
\mathrm{S} 4, \mathrm{O} 5)\end{array}$ \\
\hline
\end{tabular}


2. Peningkatan kinerja pegawai melaksanakan rekonsiliasi dan penyampaian laporan sesuai tata waktu yang ditentukan.

Sumber: Data diolah (2016)

\section{Penentuan Strategi melalui Analisis QSPM}

Menurut David dan David (2015) menerangkan bahwa QSPM adalah alat yang memungkinkan penyusun strategi untuk mengevaluasi alternatif strategi secara objektif, berdasarkan faktor keberhasilan kunci internal dan eksternal yang telah diidentifikasi sebelumnya. Seperti alat analisis perumusanstrategi lainnya, QSPM membutuhkan penilaian intuitif yang baik. Berdasarkan hasil kombinasi dari berbagai faktor baik internal dan eksternal yang dihasilkan dari analisis SWOT, maka dihasilkan empat strategi yaitu:

1) Peningkatan sumber daya manusia petugas operator dalam penyusunan laporan keuangan.

2) Peningkatan sistem aplikasi laporan keuangan dan penanganan permasalahannya.

3) Peningkatan sosialisasi, pelatihan dan bimbingan teknis penyusunan laporan keuangan sesuai PP Nomor 71 Tahun 2010.

4) Peningkatan koordinasi dan kerjasama berbagai pihak.

Dengan analisis QSPM didapatkan hasil Total Nilai Daya Tarik/Bobot Kepentingan (Total Attractiveness Scores/TAS) yang tersaji dalam Tabel 9.

Tabel 9 Hasil penilaian TAS atas matriks perencanaan strategis kuantitatif

\begin{tabular}{rlc}
\hline No. & \multicolumn{1}{c}{ Uraian Strategi } & Nilai TAS \\
\hline $\mathbf{1}$ & $\begin{array}{l}\text { Peningkatan sumber daya manusia petugas operator dalam } \\
\text { penyusunan laporan keuangan }\end{array}$ & 6.65 \\
\hline $\mathbf{2}$ & $\begin{array}{l}\text { Peningkatan sistem aplikasi laporan keuangan dan } \\
\text { penanganan permasalahannya }\end{array}$ & 6.29 \\
$\mathbf{3}$ & $\begin{array}{l}\text { Peningkatan sosialisasi, pelatihan dan bimbingan teknis } \\
\text { penyusunan laporan keuangan sesuai PP Nomor 71 Tahun } \\
2010\end{array}$ & 4.93 \\
\hline $\mathbf{4}$ & Peningkatan koordinasi dan kerjasama berbagai pihak & 5.70 \\
\hline
\end{tabular}

Sumber: Data diolah (2016)

Berdasarkan hasil tersebut, maka ditentukan strategi kebijakan yang akan dijalankan oleh Badan Litbang dan Inovasi yaitu strategi peningkatan sumber daya manusia terutama petugas operator sesuai kriteria dan pendidikan serta peningkatan peran dan tanggung jawab pimpinan terhadap laporan keuangan. Setelah ditentukan strategi yang akan dijalankan, maka selanjutnya dibuatkan rancangan program yang disajikan dalam tabel 10 .

Tabel 10 Perancangan Strategi, Kebijakan, Program dan Kegiatan

\begin{tabular}{|c|c|c|c|c|}
\hline Strategi & Kebijakan & Program & Kegiatan & $\begin{array}{c}\text { Penanggung } \\
\text { Jawab }\end{array}$ \\
\hline
\end{tabular}




\begin{tabular}{|c|c|c|c|c|c|c|}
\hline \multirow[t]{2}{*}{$\begin{array}{l}\text { Peningkatan } \\
\text { sumber daya } \\
\text { manusia } \\
\text { petugas } \\
\text { operator } \\
\text { dalam } \\
\text { penyusunan } \\
\text { laporan } \\
\text { keuangan }\end{array}$} & $\begin{array}{l}\text { Pencapaian } \\
\text { rencana } \\
\text { program dan } \\
\text { kegiatan } \\
\text { litbang dan } \\
\text { tranparansi } \\
\text { keuangan } \\
\text { K/L }\end{array}$ & 1. & $\begin{array}{l}\text { Peningkatan } \\
\text { sumberdaya } \\
\text { manusia } \\
\text { dengan } \\
\text { kualifikasi } \\
\text { akuntansi }\end{array}$ & 1. & $\begin{array}{l}\text { Pengadaan } \\
\text { SDM berlatar } \\
\text { belakang } \\
\text { akuntansi } \\
\text { Formasi } \\
\text { jabatan } \\
\text { operator } \\
\text { keuangan } \\
\text { Pemberian } \\
\text { beasiswa } \\
\text { jenjang S1 } \\
\text { Akuntansi }\end{array}$ & $\begin{array}{l}\text { Kepala Bagian } \\
\text { Kepegawaian, } \\
\text { Hukum dan } \\
\text { Ortala } \\
\text { Kepala Bagian } \\
\text { Kepegawaian, } \\
\text { Hukum dan } \\
\text { Ortala }\end{array}$ \\
\hline & & 2. & $\begin{array}{l}\text { Peningkatan } \\
\text { peran dan } \\
\text { tanggung- } \\
\text { jawab } \\
\text { pimpinan }\end{array}$ & 4. & $\begin{array}{l}\text { Sosialisasi } \\
\text { Penyusunan } \\
\text { Laporan } \\
\text { Keuangan } \\
\text { kepada Kepala } \\
\text { Balai lingkup } \\
\text { Badan Litbang } \\
\text { dan Inovasi }\end{array}$ & $\begin{array}{l}\text { Kepala Bagian } \\
\text { Keuangan dan } \\
\text { Umum }\end{array}$ \\
\hline
\end{tabular}

Sumber: Data diolah (2016)

Peningkatan SDM dengan kualifikasi atau latar belakang yang sesuai jabatan dan peran serta tanggung jawab pimpinan merupakan titik kritis yang harus segera dilaksanakan oleh Sekretaris Badan selaku pemangku kebijakan. Menurut Trivellas et al. (2015) menyatakan bahwa karyawan yang dilengkapi dengan kompetensi yang tinggi terbukti menghasilkan hasil kerja yang semakin meningkat. Program peningkatan SDM dengan kualifikasi dan latar belakang seusai jabatan dilaksanakan dengan kegiatan: 1) Pengadaan SDM berlatar belakang pendidikan akuntansi, dengan pemenuhan kebutuhan SDM yang memiliki latar belakang akuntansi, maka efektivitas dan efisensi dalam lembaga pemerintah akan semakin baik. Menurut Kartasasmita (1997) penyusunan formasi Pegawai Negeri Sipil yang bertujuan untuk memperoleh komposisi/ susunan/struktur Pegawai Negeri Sipil yang tepat dalam hal jabatan, pangkat, kompetensi, jumlah, sehingga dicapai efektivitas dan efisiensi dalam organisasi publik/pemerintah, 2) penentuan kebutuhan formasi jabatan petugas operator dengan usulan formasi pegawai untuk pemenuhan kebutuhan SDM di bagian keuangan. Menurut Yatim (2014) analisis jabatan perlu dilakukan untuk mengetahui kebutuhan dan beban kerja yang dibutuhkan dalam penyusunan formasi pegawai negeri, 3) pemberian beasiswa jenjang S1 Akuntansi bagi petugas operator yang masih mempunyai latar belakang pendidikan SMA atau Diploma. Pemberian beasiswa bertujuan untuk meningkatkan pengetahuan petugas operator dalam bidang akuntansi, terutama berbasis akrual. Selain itu bertujuan meningkatkan kualitas laporan keuangan.

Program selanjutnya adalah program peningkatan peran dan tanggung jawab pimpinan dengan kegiatan Sosialisasi Penyusunan Laporan Keuangan kepada Kepala Balai lingkup Badan Litbang dan Inovasi. Kegiatan ini harus segera dilakukan mengingat tanggung jawab kepala kantor terhadap laporan keuangan instansinya sangat penting. Menurut Ratnawati dan Arnold (2011) bahwa peran kabag dan 
kasubag dalam pelaksanaan aktivitas berbagai bagian pada pemerintah daerah menjadi suatu yang penting.

Kegiatan tersebut sangat diperlukan mengingat saat ini laporan keuangan tingkat kementerian mendapatkan opini Wajar Dengan Pengecualian (WDP). Kegiatan sosialisasi penyusunan laporan keuangan kepada atasan langsung, diharapkan meningkatkan tanggung jawab dan kepedulian terhadap pentingnya kualitas laporan keuangan saat ini. Laporan keuangan merupakan gambaran pengelolaan kinerja keuangan suatu lembaga pemerintahan.

\section{SIMPULAN DAN SARAN}

\section{Simpulan}

1. Masih terdapat petugas operator yang belum mampu menyajikan laporan keuangan dengan baik dan wajar sesuai PP Nomor 71 Tahun 2010 sehingga diperlukan adanya sosialisasi dan bimbingan teknis untuk meningkatkan kompetensinya. Untuk selanjutnya perlu dilakukan pengadaan SDM yang berlatar belakang akuntansi, sebagai pemenuhan kebutuhan petugas operator. Bagi atasan langsung atau kepala satuan kerja, belum sepenuhnya memahami pentingnya laporan keuangan sehingga masih terdapat laporan keuangan yang belum sesuai pengungkapan dan kewajarannya.

2. Implementasi aplikasi sistem akuntansi berbasis akrual masih terkendala masalah integrasi antar aplikasi, seiring dengan faktor kompetensi dan latar belakang pendidikan petugas operator yang belum memahami aplikasi akuntansi berbasis akrual berpengaruh terhadap kualitas laporan keuangan. Untuk penanganan masalah tersebut, Badan Litbang dan Inovasi berkoordinasi dengan pihak eksternal yaitu Biro Keuangan dan Kementerian Keuangan untuk lebih mengoptimalkan aplikasi berbasis akrual tersebut melalui bimbingan teknis.

3. Peningkatan kemampuan dan kompetensi petugas operator penyusun laporan keuangan melalui sosialisasi dan bimbingan teknis selama ini jarang dilakukan sehingga berpengaruh pada penyusunan laporan keuangan yang berkualitas. Hal tersebut disebabkan ketersediaan anggaran yang ada sangat terbatas. Kualitas laporan keuangan yang sesuai dengan peraturan perundangan sangat diperlukan untuk mencapai opini wajar tanpa pengecualian.

4. Strategi yang ditentukan oleh pemangku kebijakan adalah meningkatkan kapasitas sumber daya manusia sesuai dengan kriteria dan tingkat pendidikan yang menjadi dasar untuk menghasilkan laporan keuangan yang berkualitas. Peran serta tanggungjawab pimpinan terhadap penyusunan laporan juga sangat diperlukan untuk menghasilkan laporan keuangan yang wajar dan transparan.

\section{Saran}

Pemenuhan kebutuhan SDM terutama di bidang akuntansi harus segera dilakukan mengingat selama ini petugas operator satuan kerja belum sepenuhnya memahami mengenai akuntansi berbasis akrual. Pelaksanaan sosialisasi dan bimbingan teknis mengenai penyusunan akuntansi merupakan hal yang mendeak untuk dilakukan. Selanjutnya pengadaan atau rekrutmen SDM untuk petugas operator harus dilakukan dengan persyaratan latar belakang pendidikan di bidang akuntansi. 
Dalam program jangka panjang, untuk meningkatkan kompetensi dan pengetahuan di bidang akuntansi, kementerian dapat memberikan beasiswa pendidikan S1 Akuntansi bagi petugas operator. Pemberian beasiswa tersebut diberikan kepada petugas operator yang memiliki latar belakang SMA atau Diploma.

Peningkatan aplikasi sistem akuntansi berbasis akrual yang sudah terintegrasi satu sama lain sehingga memudahkan petugas operator dalam menyusun dan menyajikan laporan keuangan yang berkualitas. Kementerian Keuangan dapat memberikan solusi terhadap setiap permasalahan yang berkaitan dengan aplikasi penyusun laporan keuangan yang terintegrasi. 


\section{DAFTAR PUSTAKA}

Bastian I. 2010. Akuntansi Sektor Publik: Suatu Pengantar. Jakarta (ID): Erlangga

Charlina O, Husaini A. 2013. Pengaruh Implementasi Pengelolaan Keuangan dan Pengalaman Kerja terhadap Kualitas Laporan Keuangan Komisi Pemilihan Umum. J Fairness 3(3): 82-94.

David FR, David FR. 2015. Strategic Management: Concepts and Cases. 15th Ed. Essex (GB): Pearson Education Limited.

Dessler G. 2015. Human Resources Management, 4th Ed. New Jersey (US): Pearson Education Inc.

Handayani D. 2012. Good Governance dan Kualitas Laporan Keuangan Pemerintah. Jurnal Akuntansi Keuangan dan Bisnis Vol. 5: 12-16

Horngren CT, Harrison WT Jr. 1996. Akuntansi. Gania G, Pujiati D, penerjemah; Hardani W, Saat S, editor. Jakarta (ID) Penerbit Erlangga. Terjemahan dari: Accounting. Ed ke-7

Juwita R. 2013. Pengaruh Implementasi Standar Akuntansi Pemerintahan dan Sistem Informasi Akuntansi terhadap Kualitas Laporan Keuangan. J Trikonomika 2(2): 201-214.

Kartasasmita G. 1997. Administrasi Pembangunan: Perkembangan Pemikiran dan Praktiknya di Indonesia. Jakarta (ID): Pustaka LP3ES Indonesia

Nugraheni P, Subaweh I. 2008. Pengaruh Penerapan Standar Akuntansi Pemerintahan Terhadap Kualitas Laporan Keuangan. Gunadarma University J Elektronik (2008): 46-56

Nofanti L, Suseno NS. 2014. Factors affecting implementation of good government governance (GGG) and their implications towards performance accountability. J Procedia - Social and Behavioral Sciences 164 (2014): 98 - 105

Perdanawati, LPVI. 2014. Pengaruh Unsur-unsur Kepuasan Pengguna pada Efisiensi dan Efektivitas Kerja Pengguna Aplikasi Sistem Akuntansi Instansi di Satuan Kerja Pendidikan Tinggi di Provinsi Bali [tesis]. Bali (ID): Universitas Udayana.

Pemerintah Republik Indonesia. 2010. Peraturan Pemerintah Republik Indonesia Nomor 71 Tahun 2010 tentang Standar Akuntansi Pemerintahan. Jakarta (ID): Sekretariat Negara.

Prasetya GE. 2005. Penyusunan dan Analisis Laporan Keuangan Pemerintah Daerah. Yogyakarta (ID): Andi Publisher

Rangkuti F. 2015. Teknik Membedah Kasus Bisnis: Analisis SWOT. Jakarta (ID): PT Gramedia Pustaka Utama

Ratnawati J, Arnold CWP. 2011. Peran Manajerial Pengelola Keuangan Daerah dan Fungsi Pemeriksaan Intern serta Pengaruhnya terhadap Kinerja Pemerintah Daerah. J Dian. 11(2): 182-191. ISSN: 14123088

Solihin I. 2012. Manajemen Strategik. Jakarta (ID): Erlangga

Trivellas P, Kakkos N, Blanas N, Santouridis I. 2015. The Impact of Career Satisfaction on Job Performance in Accounting Firms. The Mediating Effect of General Competencies. Procedia Economics and Finance 33 ( 2015 ) 468 - 476.

Wati KD, Herawati NT, Sinarwati NK. 2014. Pengaruh Kompetensi SD, Penerapan SAP dan Sistem Akuntansi Keuangan Daerah terhadap Kualitas Laporan Keuangan Daerah. e-Journal Universitas Pendidikan Ganesha 2 (1)

Yatim IA, Supriyono B, Hardjanto I. 2014. Perencanaan Pembangunan Sumber Daya Aparatur Melalui Penyusunan Forrmasi Pegawai Negeri Sipil Daerah di Kabupaten Magetan. J Wacana. [Internet] $\begin{array}{lllllll}\text { [diunduh } 2016 & \text { Jul 18]; } & \text { 17(2): } & \text { 47-57. } & \text { Tersedia }\end{array}$ http://wacana.ub.ac.id/index.php/wacana/article/view/304.

Yuliani S, Nadirsyah, Bakar U. 2010 Pengaruh Pemahaman Akuntansi, Pemanfaatan Sistem Informasi Akuntansi Keuangan Daerah dan Peran Internal Audit terhadap Kualitas Laporan Keuangan Pemerintah Daerah (Studi pada Pemerintah Kota Banda Aceh). J Telaah dan Riset Akuntansi 3(2): 206-220 